\title{
The effects of abiotic variables on detritus decomposition in Brazilian subtropical mangroves
}

Efeito das variáveis abióticas sobre a decomposição de detritos em mangues subtropicais brasileiros

\author{
Renan de Souza Rezende ${ }^{1,2}$, Marcelo de Oliveira Pinto ${ }^{3}$, \\ José Francisco Gonçalves Jr. ${ }^{2}$ and Mauricio Mello Petrucio ${ }^{1,3}$
}

${ }^{1}$ Programa de Pós-graduação em Ecologia, Universidade Federal de Santa Catarina - UFSC, CEP 88040-970, Florianópolis, SC, Brazil, e-mail: renanrezende30@gmail.com; petrucio@ccb.ufsc.br ${ }^{2}$ Departamento de Ecologia, Universidade de Brasília - UnB, CEP 70910-900, Brasília, DF, Brazil e-mail: jfunior@unb.br

${ }^{3}$ Programa de Pós-Graduação em Biologia Vegetal, Universidade Federal de Santa Catarina - UFSC, CEP 88040-970, Florianópolis, SC, Brazil, e-mail: marcelo79ufsc@yahoo.com.br

\begin{abstract}
Aim: The objective of this study was to determine the rate of decomposition of two dominant arboreal species (Rhizophora mangle and Avicennia schaueriana) in two Brazilian subtropical mangroves (Ratones and Itacorubi) and their relationship with abiotic factors during two periods of the year (winter and summer). Methods: Senescent leaves $(4 \pm 0.1 \mathrm{~g}$ dry weight) were placed into litter bags $(20 \times 25 \mathrm{~cm}$ with $1 \mathrm{~cm}$ mesh size) and submersed in mangrove forests during a winter and a summer sampling period. Replicates $(n=4)$ of each detritus sample were obtained from the mangroves after 7,15 , 30, 60, 90 and 120 days of incubation during both time periods. During each period, in situ measurements were taken to obtain the temperature, electrical conductivity, $\mathrm{pH}$, and dissolved oxygen in the water column. Results: The species $R$. mangle and $A$. schaueriana exhibited slow rates of decomposition at Itacorubi and intermediate rates at Ratones during the winter, while quick rates were observed at both sites during the summer; this result suggested that water temperature is an influential factor. There was no difference in the loss of mass between the sites during the winter, but in the summer, the highest values were observed for $R$. mangle in Ratones site. The highest summer temperatures were negatively associated with mass loss, suggesting that the temperature is an influential factor. During the winter, remaining mass was associated negatively with electrical conductivity, possibly because of a greater resource available to decomposing communities, and it was also positively associated with oxygen, revealing a pattern opposite to that observed in the literature. Conclusions: Our results showed that decomposition accelerated with higher temperatures and that electrical conductivity decelerated with increased dissolved oxygen, confirming the effects of abiotic factors on both detritus decomposition and mangrove functioning.
\end{abstract}

Keywords: leaf breakdown, Rhizophora mangle, Avicennia schaueriana, subtropical coastal region, temperatures, electrical conductivity, dissolved oxygen.

Resumo: Objetivo: O objetivo deste trabalho foi determinar a taxa de decomposição de duas espécies vegetais (Rhizophora mangle e Avicennia schaueriana) dominantes em manguezais subtropicais (Ratones e Itacorubi), e sua relaçáo com os fatores abióticos ao longo de dois períodos do ano; Métodos: Folhas senescentes ( $4 \pm 0,1 \mathrm{~g}$ peso seco) foram colocadas em "litter bags" $(20 \times 25 \mathrm{~cm}$ e malha de $1 \mathrm{~cm})$ e submersas em ambos os manguezais nos períodos de inverno e verão. As replicadas $(\mathrm{n}=4)$ de cada detrito nos dois diferentes manguezais foram então retiradas após 7, 15, 30, 60, 90 e 120 dias de incubação e aferiu-se in situ a temperatura, condutividade elétrica, $\mathrm{pH}$ e oxigênio dissolvido da coluna da água; Resultados: A taxa de decomposição de $R$. mangle e $A$. schaueriana foram lentos em Itacorubi e intermediários em Ratones no inverno, mas no verão em ambos os manguezais foram rápidos, indicando influência da temperatura da água. Não se observou diferença da perda de massa entre os locais no inverno, devido a uma baixa variação dos fatores ambientais. Já no verão houve diferença na perda de massa entre detritos, com os maiores valores em $R$. mangle (maior em Ratones). Quando relacionamos as variáveis abióticas com a massa remanescente total, novamente observou-se uma associação negativa apenas com temperaturas mais altas no verão. No inverno a massa remanescente se associou negativamente com a condutividade elétrica, possivelmente, por maior quantidade de recurso disponível para as comunidades decompositoras, e também, positivamente com o oxigênio da água, revelando um padrão contrario ao observado na literatura; Conclusóes: Nossos resultados mostraram que a decomposição foi acelerada pelos valores mais elevados de temperatura e condutividade elétrica, e menores concentrações de oxigênio dissolvido, confirmando os efeitos destas variáveis abióticas sobre o processamento dos detritos e funcionamento dos mangues.

Palavras-chave: decomposição foliar, Rhizophora mangle, Avicennia schaueriana, região costeira subtropical, temperaturas, condutividade elétrica, oxigênio dissolvido. 


\section{Introduction}

Mangroves are coastal ecosystems that serve as a transition between sea and land, and they are present in tropical and subtropical regions in areas that are subject to tide regimes (Ong, 1995; Silva et al., 2005). Generally, mangroves occur in sheltered areas (e.g. estuaries, bays and lagoons) and present favorable feeding and refuge conditions for many species; they are considered to be generators of many ecosystem services (Silva et al., 2005). It is estimated that mangroves are responsible for the exportation of $10 \%$ of the global terrestrial dissolved organic carbon into the oceans, yet their limited territorial extent $(0.1 \%$ of cover on all continents) highlights their importance and fragility (Allan and Castillo, 2007). Therefore, studies on organic carbon cycling and other nutrients can contribute to a better understanding of ecosystem function and aid in restoration and conservation activities (Fernandes, 2003; Shafer and Roberts, 2007).

In mangroves, allochthonous detritus (e.g. leaves, branches, fruits and flowers) are responsible for providing a large portion of the organic carbon and nutrients that are important for the energy balance of the ecosystem (Fernandes, 2003; Allan and Castillo, 2007). Information concerning the cycling of organic material in mangroves will contribute to a more detailed comprehension of the energy flux in these environments, specifically regarding decomposition, which is a fundamental process in this cycle (Sánchez-Andrés et al., 2010; Gonçalves Junior et al., 2012b). The allochthonous leaf litter decomposition process directly affects the release of nutrients into the environment, liberating them back to the trophic cascades (Fernandes, 2003; Gonçalves Junior et al., 2012b). This leaf breakdown causes the carbon in the biomass that is incorporated from photosynthesis to return to the atmosphere as $\mathrm{CO}_{2}$, where part of it, along with other minerals, is available to and reincorporated by plants and other organisms (Shafer and Roberts, 2007; Gonçalves Junior et al., 2012b).

The leaf breakdown process can be divided into the following three phases: 1) the leaching of chemical components, 2) the conditioning of detritus by microorganisms, and 3) fragmentation by aquatic invertebrates and/or by physical environmental factors, which occur simultaneously and interact throughout the whole process (Gessner et al., 1999; Granek and Ruttenberg, 2008). This system is driven by three variables: biological, leaf-litter characteristics and the environment (Allan and Castillio, 2007; Castilho-
Westphal et al., 2008). The first variable primarily refers to the structure of the decomposer community (invertebrates and micro-organisms), where a higher abundance and biomass drives greater decomposition (Gessner et al., 1999). The second, leaf-litter characteristics, determines its palatability, where less hardness, the concentration of secondary compounds and greater nutrient concentration can lead to a higher loss in mass (Gessner et al., 1999). The third variable is associated with the physical and chemical conditions of the environment because higher temperatures, greater electrical conductivity and increased dissolved oxygen and nutrient concentrations in the water can positively contribute to decomposition (Gessner et al., 1999). Specifically in mangroves, we must consider the stronger effects of salinity concentration variability, which may be a key variable for leaf litter decomposition, observing a negative effect due to acute increase in salt concentration (Rietz and Haynes, 2003; Roache et al., 2006; Gafner and Robinson, 2007; Mfilinge and Tsuchiya, 2008). But this depends on the decay time considered, observed positive relationships in initial and final stages of decomposition (Quintino et al., 2009).

This study assumed that the leaf-breakdown process accelerates with increasing temperature, electrical conductivity and dissolved oxygen (Gulis and Suberkropp, 2003; Rezende et al., 2010) and is primarily affected by changes in the environment that occur along a temporal scale (Roache et al., 2006; Gafner and Robinson, 2007; Mfilinge and Tsuchiya, 2008; Gonçalves Junior et al., 2006a; $2012 a, b)$. The hypothesis of this study is that the highest leaf-breakdown rates should occur with elevated water temperatures, electrical conductivity, and dissolved oxygen concentrations. The present study aims to determine the leaf-breakdown rate of two arboreal species (Rhizophora mangle Linnaeus and Avicennia schaueriana Stapf and Leechm. ex Moldenke) in two subtropical mangroves and their relationship with water temperature, electrical conductivity and dissolved oxygen during the winter and summer.

\section{Material and Methods}

\subsection{Study area}

The study was performed in two subtropical mangroves, Itacorubi ( $27^{\circ} 35^{\prime} 31^{\prime \prime} \mathrm{S}$; $48^{\circ} 31^{\prime} 33^{\prime \prime}$ $\mathrm{W})$ and Ratones (27 $27^{\prime} 30^{\prime \prime} \mathrm{S}$; $\left.48^{\circ} 31^{\prime} 43^{\prime \prime} \mathrm{W}\right)$, both situated in the northern bay on the Island of Santa Catarina in Brazil (Figure 1). The climate is 


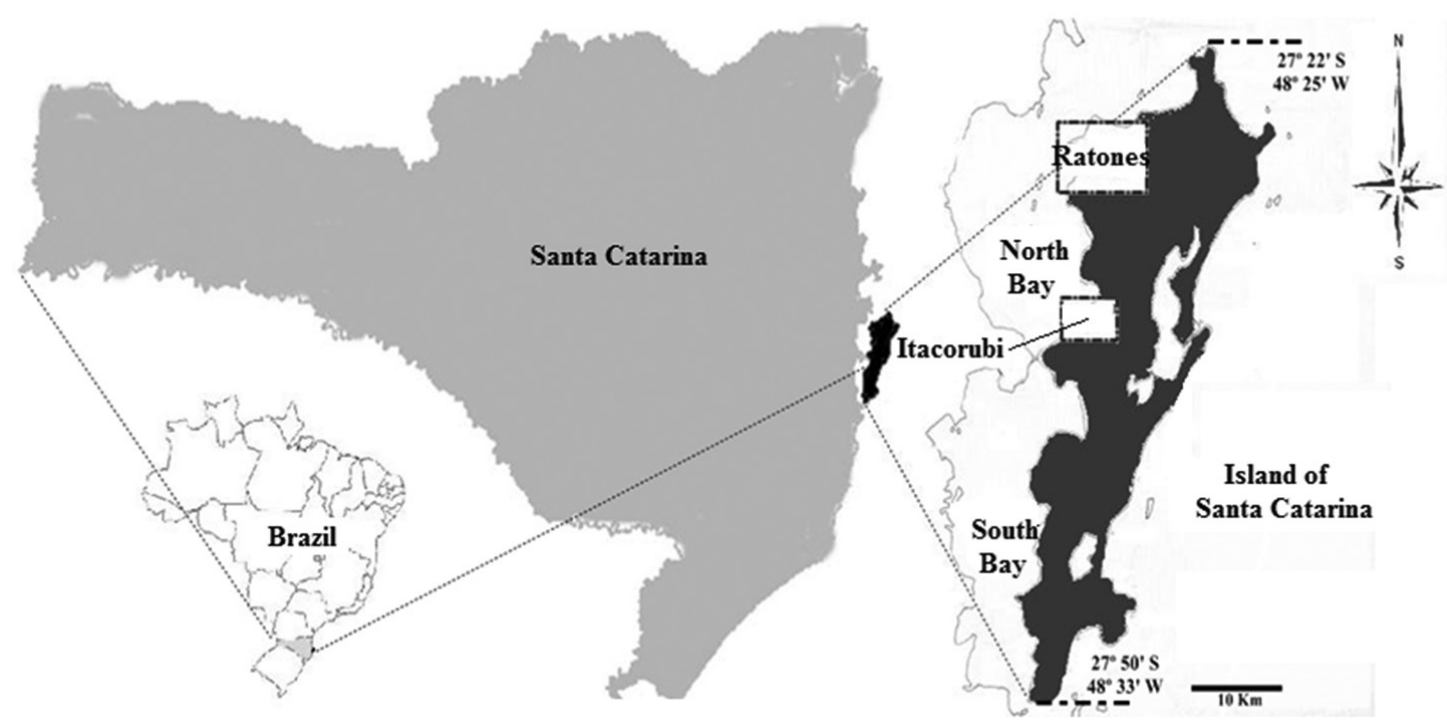

Figure 1. Map of geographic location of study areas (Itacorubi and Ratones mangroves) in the municipal of Florianópolis/SC, Brazil.

subtropical and humid, with well-distributed rainfall throughout the year and with well-defined seasons (hot summer and cold winter). These mangroves are influenced by preponderant winds from the north/ northeast quadrant. Oceanographically, the tides are micro-tides $(<2 \mathrm{~m})$ with semi-diurnal regimes and maximum amplitudes of $1.4 \mathrm{~m}$.

The Itacorubi mangrove is located in the estuarine Itacorubi River Watershed, on the west coast of Santa Catarina Island (area of $1.62 \mathrm{~km}^{2}$ with a perimeter of $5.8 \mathrm{~km}$ ) and is formed by groves of $A$. schaueriana, Laguncularia racemosa and $R$. mangle. The Ratones mangrove is situated in the Ratones River Watershed on the northeastern sites of the island. It is protected by the Estação Ecológica de Carijós (ESEC; area of $6.25 \mathrm{~km}^{2}$ with a perimeter of $33 \mathrm{~km}$ ), comprising the same vegetative species as cited above. Both mangroves have similar conservation characteristics, despite some anthropic impacts on Ratones.

\subsection{Experimental procedures}

This study was conducted in $20 \mathrm{~m}^{2}$ flooded areas in an inter-tidal zone that was $5 \mathrm{~m}$ inland from the border of the Itacorubi and Ratones mangroves. Senescent leaves newly fall of $R$. mangle and $A$. schaueriana were randomly collected in both areas. In the laboratory, the leaves were analyzed to select the best conditions for the experiment and to estimate the initial wet mass. Linear regression curves were used to convert the wet mass into an initial dry mass $(0.5,1,3,5,10$ and $20 \mathrm{~g}$, respectively) for both species, which were then dried in an oven at $60{ }^{\circ} \mathrm{C}$ for 72 hours.

The experiments were conducted from July to November (2008), which corresponds to the winter and spring seasons (but just called winter, which is longer at this station), and from February to June (2009), which corresponds to the summer and autumn seasons (but just called summer, as it is longer at this station). We used litter bags (20 $\times 25 \mathrm{~cm}$ and $1 \mathrm{~cm}$ mesh size) that were $4 \pm 0.1 \mathrm{~g}$ for senescent leaves samples, which were collected after $7,15,30,60,90$ and 120 days of incubation. A total of 48 litter bags were separated into rows with $10 \mathrm{~m}$ between each row, and these bags were placed in different areas along the border of the mangrove, with 4 replicas for each $(50 \mathrm{~cm}$ apart from each other) site studied. A total of 96 litter bags were used in the overall experiment (Figure 2). At each sampling site, the litter bags were placed in individual plastic bags and transported from the field to the laboratory in an icebox $\left(10^{\circ} \mathrm{C}\right)$.

During incubation, we removed samples to measure the electrical conductivity, $\mathrm{pH}$ (YSI multi-analyzer, model 85 ), water temperature and dissolved oxygen (oxymeter AT170) in the water column. In costal environmental we can use the conductivity to estimate the salinity.

\subsection{Data treatment}

The leaf-breakdown rates $(k)$ were calculated according to a negative exponential model using data corresponding to the percent mass loss and time $(W t=W 0 e)$ (Graça et al., 2005). In this model, 


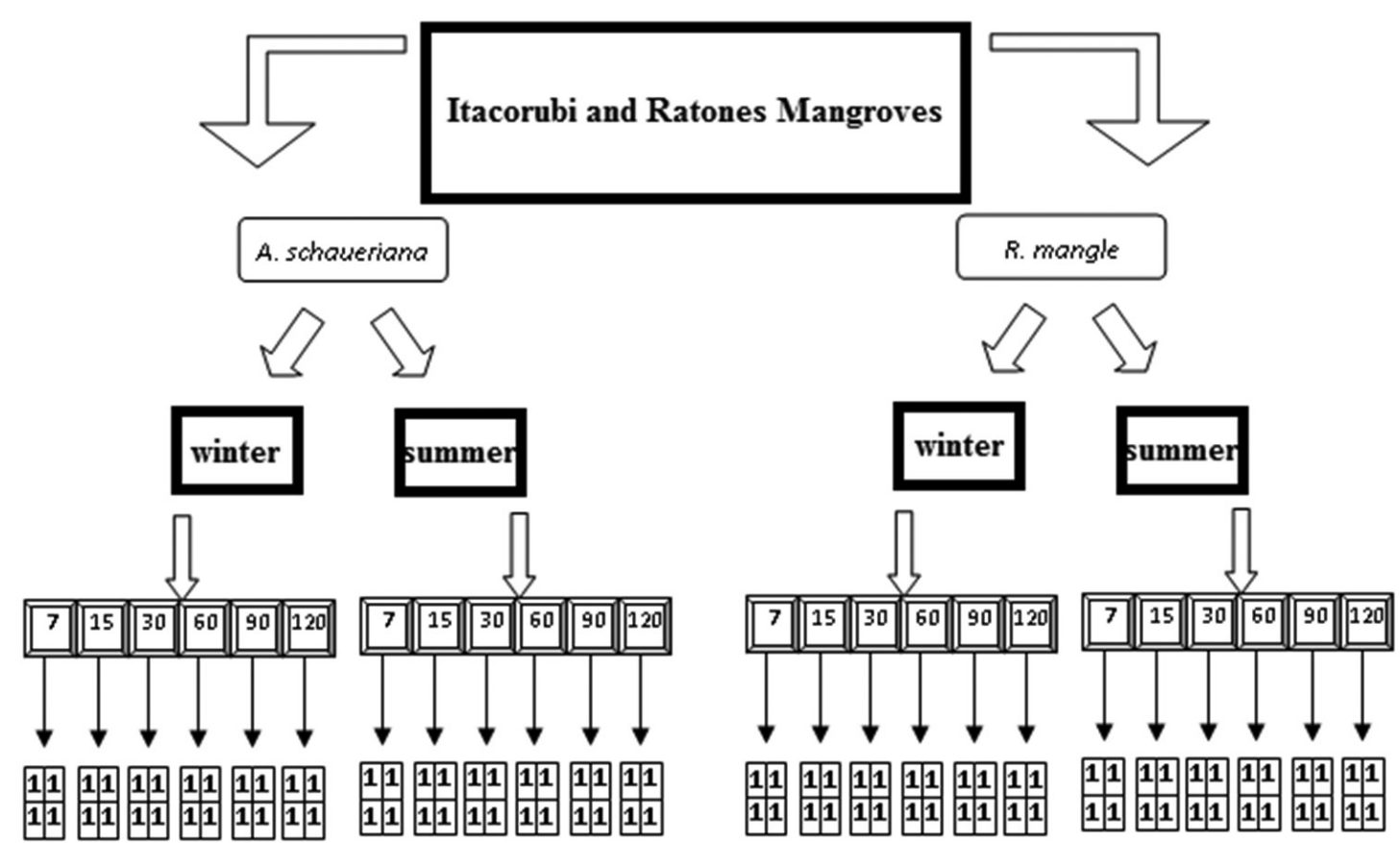

Figure 2. Sample design showing the replicas (4), in the times (7, 15, 30, 60, 90 and 120 days), seasons (winter and summer), senescent leaves (A. schaueriana and $R$. mangle) and local studies (Itacorubi and Ratones mangroves).

$k$ is the exponential decay constant, $W t$ represents the mass remaining after $t$ days, and $W_{0}$ is the initial dry mass at the instant $t_{0}$. The differences of mass loss (Ln-transformed, dependent variable) for each species, period and site (categorical variables) per sample time (continuous variable) were compared using an analysis of covariance (ANCOVA; significance level of 0.05) (Crawley, 2007). The water temperature, electrical conductivity, $\mathrm{pH}$ and dissolved oxygen (dependent variable) values were tested using one-way ANOVAs (significance level of 0.05 ) between periods (summer and winter) and sites (Ratones and Itacorubi) (categorical variables) (Crawley, 2007).

Regression trees were used to determine the influence of the environmental variables on the remaining mass of the leaf litter (significance level of 0.05); this process is useful for exploring, describing, and predicting relationships between a variable and environmental characteristics by grouping via the repeated division of data (De'Ath, 2002). Each division point is defined using a simple rule that is based on environmental values. A constant variable is attributed to each terminal node, where the best and simplest value is the average of all cases, which belong to this node through a determined partitioning. Such groupings that show the dependence on environmental data are graphically represented in tree-form, enabling the analysis of complex ecological data that often includes disequilibrium, missing values, non-linear relationships between variables and high-order interactions, and these groupings enable patterns to be predicted using only the available environmental data (De'Ath, 2002). The normality of the data was tested using the Kolmogorov-Smirnov test, and the data were transformed using the Ln-function when required. All analyses were performed using the $\mathrm{R}$ program (R Development Core Team, 2008).

\section{Results}

\subsection{Abiotic parameters of water}

The water temperature, $\mathrm{pH}$ and dissolved oxygen values did not differ between the Itacorubi and Ratones mangroves during the two sampling periods. However, the electrical conductivity values were significantly different during the summer (with higher values occurring in the Itacorubi mangrove); but the values did not differ between the two sites during the winter (Tables 1 and 2). When comparing the abiotic variables in summer and winter at the two sites, the temperatures significantly differed (with the highest values occurring in the summer). However, the electrical conductivity, $\mathrm{pH}$ and dissolved oxygen did not differ between sampling periods at the sites (Table 1 and 2). 
Table 1. Values in sampled days and average values and standard error (SE) for electrical conductivity $\left(\mathrm{mS}_{\mathrm{cm}} \mathrm{cm}^{-1}\right), \mathrm{pH}$, dissolved oxygen $\left(\mathrm{mg} \cdot \mathrm{L}^{-1}\right)$, water temperature $\left({ }^{\circ} \mathrm{C}\right)$ and variation of the seas (meters) during the winter and summer season in the mangroves of Itacorubi and Ratones assessed during the study period.

\begin{tabular}{|c|c|c|c|c|c|c|}
\hline Mangrove & Days & Conductivity & $\mathrm{pH}$ & Oxygen & Temp & Seas \\
\hline \multicolumn{7}{|l|}{ Winter } \\
\hline & 0 & 35 & 6.82 & 3.77 & 18.2 & 0.2 \\
\hline & 7 & 35.56 & 6.98 & 5.44 & 21.3 & 0.4 \\
\hline & 15 & 33.5 & 6.83 & 6.94 & 20.3 & 0.4 \\
\hline \multirow[t]{8}{*}{ Itacorubi } & 30 & 18.34 & 7.2 & 2.4 & 19.6 & -0.3 \\
\hline & 60 & 33.14 & 7.24 & 6.27 & 19.5 & 0.4 \\
\hline & 90 & 30.5 & 7.02 & 6.03 & 20.2 & 0.6 \\
\hline & 120 & 32.8 & 6.74 & 6.12 & 22.6 & 0.7 \\
\hline & Average $\pm \mathrm{SE}$ & $31.26 \pm 2.42$ & $7.0 \pm 0.07$ & $5.28 \pm 0.65$ & $20.24 \pm 0.57$ & $0.34 \pm 0.08$ \\
\hline & 0 & 22.07 & 7.32 & 4.24 & 22.3 & 0.2 \\
\hline & 7 & 29.66 & 6.88 & 6.41 & 21.7 & 0.4 \\
\hline & 15 & 27.45 & 5.82 & 7.62 & 21.1 & 0.4 \\
\hline \multirow[t]{5}{*}{ Ratones } & 30 & 32.58 & 6.4 & 6.74 & 20.2 & -0.3 \\
\hline & 60 & 26.58 & 6.26 & 7.55 & 18.7 & 0.4 \\
\hline & 90 & 29.54 & 6.54 & 6.91 & 20.4 & 0.6 \\
\hline & 120 & 29.78 & 6.98 & 6.42 & 22.1 & 0.7 \\
\hline & Average $\pm \mathrm{SE}$ & $28.24 \pm 1.35$ & $6.6 \pm 0.21$ & $6.56 \pm 0.46$ & $20.93 \pm 0.51$ & $0.34 \pm 0.08$ \\
\hline \multicolumn{7}{|l|}{ Summer } \\
\hline & 0 & 33.81 & 6.75 & 3.54 & 26.1 & 0.5 \\
\hline & 7 & 34.83 & 6.34 & 3.64 & 25.2 & 0.2 \\
\hline & 15 & 28.12 & 6.89 & 4.94 & 25.7 & 0.5 \\
\hline \multirow[t]{8}{*}{ Itacorubi } & 30 & 33.94 & 6.2 & 5.3 & 23.9 & 0.6 \\
\hline & 60 & 31.92 & 6.97 & 6.1 & 23.8 & 0.3 \\
\hline & 90 & 31.33 & 6.72 & 5.63 & 20.2 & 0.4 \\
\hline & 120 & 30.88 & 7.03 & 5.42 & 19.6 & 0.5 \\
\hline & Average \pm SE & $32.12 \pm 0.93$ & $6.7 \pm 0.12$ & $4.94 \pm 0.41$ & $23.04 \pm 0.91$ & $0.42 \pm 0.05$ \\
\hline & 0 & 29.54 & 6.64 & 4.98 & 25.3 & 0.5 \\
\hline & 7 & 30.12 & 6.57 & 5.34 & 24.6 & 0.2 \\
\hline & 15 & 26.93 & 6.64 & 5.62 & 25.1 & 0.5 \\
\hline \multirow[t]{5}{*}{ Ratones } & 30 & 31.84 & 6.62 & 6.34 & 22.3 & 0.6 \\
\hline & 60 & 30.2 & 6.36 & 6.55 & 23.7 & 0.3 \\
\hline & 90 & 30.31 & 6.53 & 6.14 & 20.5 & 0.4 \\
\hline & 120 & 26.94 & 6.58 & 5.9 & 19.8 & 0.5 \\
\hline & Average $\pm S E$ & $29.41 \pm 0.74$ & $6.6 \pm 0.04$ & $5.84 \pm 0.22$ & $23.04 \pm 0.08$ & $0.42 \pm 0.05$ \\
\hline
\end{tabular}

\subsection{Leaf breakdown}

The leaf-breakdown rates $(k)$ during the winter were -0.005 and -0.007 for $R$. mangle and, -0.005 and -0.006 for $A$. schaueriana in the Ratones and Itacorubi mangroves, respectively. During the summer, the $k$ was -0.015 and -0.013 for $R$. mangle and, -0.009 and -0.01 for $A$. schaueriana in the Ratones and Itacorubi mangroves, respectively (Figure 3).

The decay rates were higher during the summer than during the winter when considering all the leaf litter at both sites. When we examined all of the detritus from all of the sites and seasons, $R$. mangle presented higher decomposition values than $A$. schaueriana. No significant difference was detected between the detritus mass loss for leaf litter in the winter season. During the summer, the leaf litter mass loss between the sites was different for A. schaueriana, with higher leaf-breakdown rates at the Ratones site. However, the same did not apply for $R$. mangle (Table 3).

When comparing the leaf litter mass loss in both mangroves, no difference was observed for A. schaueriana and $R$. mangle during the winter in the Itacorubi and Ratones mangroves. In contrast, during the summer at both the Itacorubi and Ratones sites, we observed differences in the mass loss, with higher leaf-breakdown rates for $R$. mangle than for A. schaueriana (Table 3). 
Table 2. Values of significance (p) of ANOVA test, degrees of freedom (DF) and residual (DF Res.) and values of deviance $(\mathrm{F})$, for electrical conductivity, $\mathrm{pH}$, dissolved oxygen, and water temperature between sites during the winter (A) and summer (B) and also between season in the mangroves of Itacorubi (C) and Ratones (D).

\begin{tabular}{lcccc}
\hline \multicolumn{1}{c}{ ANOVA } & DF & DF Res. & F & p \\
\hline Ratones Itacorubi & & & & \\
$\quad$ Winter .A & 1 & 12 & 0.78 & 0.39 \\
Conductivity & 1 & 12 & 3.49 & 0.08 \\
pH & 1 & 12 & 2.47 & 0.14 \\
Oxygen & 1 & 12 & 0.93 & 0.35 \\
Water Temperature & & & & \\
Summer .B & 1 & 12 & 5.73 & 0.03 \\
Conductivity & 1 & 12 & 1.08 & 0.31 \\
pH & 1 & 12 & 4.17 & 0.06 \\
Oxygen & 1 & 12 & 0.11 & 0.75 \\
Water Temperature & & & & \\
Winter x Summer & & 12 & 0.12 & 0.72 \\
Itacorubi .C & 1 & 12 & 3.87 & 0.07 \\
Conductivity & 1 & 12 & 0.23 & 0.63 \\
pH & 1 & 12 & 8.22 & 0.01 \\
Oxygen & 1 & & & \\
Water Temperature & & 12 & 0.66 & 0.42 \\
Ratones .D & 1 & 12 & 0.03 & 0.85 \\
Conductivity & 1 & 2.25 & 0.15 \\
pH & 1 & 4.76 & 0.04 \\
Oxygen & 1 & & & \\
Water Temperature & & &
\end{tabular}

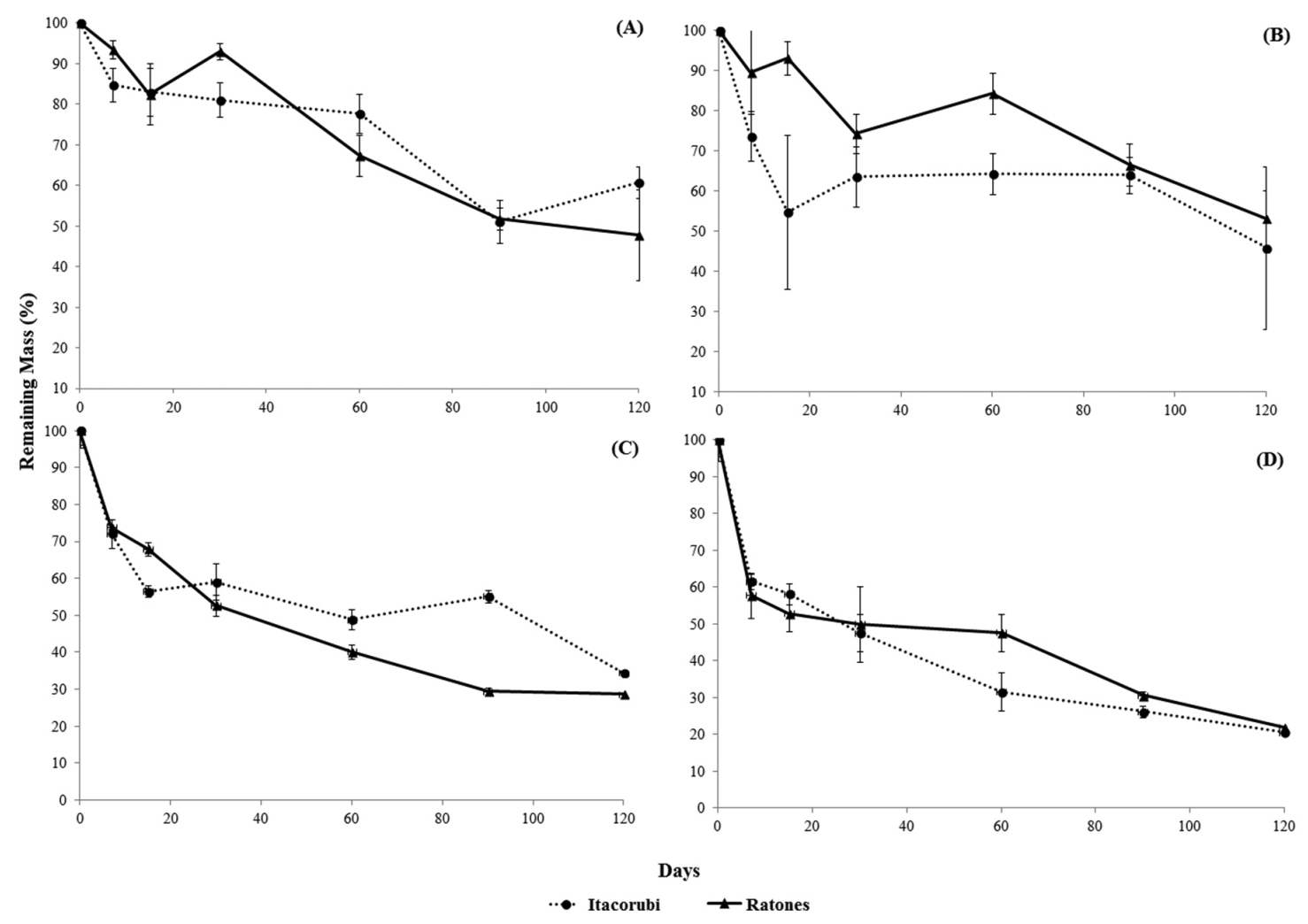

Figure 3. Averages values and standard error (vertical bars) of senescent leaves mass loss for A. schaueriana (A and C) and $R$. mangle $(\mathrm{B}$ and $\mathrm{D})$ in the winter $(\mathrm{A}$ and $\mathrm{B})$ and summer $(\mathrm{C}$ and $\mathrm{D})$ in the studied mangroves. 


\subsection{Regression tree of abiotic parameters on the remaining mass of leaves}

The regression tree revealed that the abiotic factors, which are significantly responsible for the leaf-breakdown rate, included dissolved oxygen and electrical conductivity in the winter (Figure 4A) and temperature in the summer (Figure 4B). In the winter season, dissolved oxygen was found to be the best explanatory variable, with reported values of $5.73 \mathrm{mg} . \mathrm{L}^{-1}$ or higher, an average of $87.91 \%$ of the remaining mass. For values below this concentration
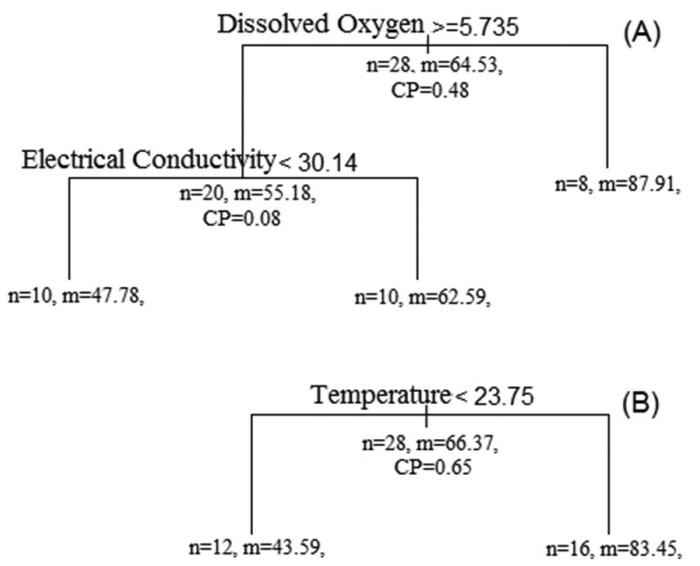

Figure 4. Regression Tree with replicate values (n), significant parameter average $(\mathrm{m})$ and parameter complexity at each knot (CP) divided by the values of water temperature, electrical conductivity, $\mathrm{pH}$ and dissolved oxygen in function of the percent of remaining mass of leaf detritus in the mangroves of Ratones and Itacorubi during the winter (A) and summer (B) seasons. of dissolved oxygen, electrical conductivity was responsible for driving the mass loss. Values lower than $30.14 \mathrm{mS} / \mathrm{cm}$ were responsible for $62.69 \%$ of the remaining mass, while values greater than this were responsible for an average of $47.78 \%$ of the remaining mass. In the summer, temperatures below $23.75{ }^{\circ} \mathrm{C}$ resulted in a remaining mass of $83.45 \%$, while values above this resulted in an average remaining mass of $43.6 \%$.

\section{Discussion}

According to the classifications proposed by Petersen and Cummins (1974), the leaf breakdown rates for $R$. mangle and $A$. schaueriana in the winter were slow at Itacorubi $(\mathrm{k}<-0.005)$ and intermediate at Ratones $(-0.010>\mathrm{k}>-0.005)$. In the summer, both sites and species were classified as faster ( $\mathrm{k}>-0.010)$, with the exception of $A$. schaueriana at Itacorubi, which had intermediate rates. This classification was originally created for temperate environments, although it is frequently used for diverse tropical environments (Bianchini Junior, 1999; Wantzen and Wagner, 2006; Moretti et al., 2007a, b; Rezende et al., 2010; Gonçalves Junior et al., 2012a, b). However, using the method of Gonçalves et al. (2013), who developed a classification specifically for Brazilian tropical systems, we observed that all decay rates were intermediate $(-0.0173>\mathrm{k}>-0.0041)$ but around the upper range. These decay rates indicated that the litter in the studied area is quickly processed, reflecting its importance for ecosystem functioning and biological diversity (Ong, 1995; Silva et al., 2005; Bouillon et al., 2008).

Table 3. Values of significance (p) of ANCOVA test, degrees of freedom (DF) and residual (DF Res.) and values of deviance $(F)$, between season $(A)$, senescent leaves $(B)$, sites in senescent leaves $(C$ and $D)$, and senescent leaves in sites ( $\mathrm{E}$ and $\mathrm{F})$.

\begin{tabular}{|c|c|c|c|c|}
\hline ANCOVA & DF & DF Res. & $\mathbf{F}$ & $\mathbf{p}$ \\
\hline Winter $x$ Summer.$A$ & 1 & 184 & 179 & $<0.01$ \\
\hline R. mangle $x$ A. schaueriana. $\mathrm{B}$ & 1 & 184 & 5.34 & 0.02 \\
\hline \multicolumn{5}{|l|}{ A. schaueriana.C } \\
\hline Ratones $\times$ Itacorubi (Winter) & 1 & 44 & 0.13 & 0.71 \\
\hline Ratones $\times$ Itacorubi (Summer) & 1 & 44 & 12.15 & 0.01 \\
\hline \multicolumn{5}{|l|}{ R. mangle.D } \\
\hline Ratones x Itacorubi (Winter) & 1 & 42 & 2.73 & 0.08 \\
\hline Ratones x Itacorubi (Summer) & 1 & 45 & 1.37 & 0.24 \\
\hline \multicolumn{5}{|l|}{ Ratones .E } \\
\hline R. mangle $\times$ A. schaueriana (Winter) & 1 & 45 & 3.65 & 0.06 \\
\hline R. mangle $x$ A. schaueriana (Summer) & 1 & 45 & 5.54 & 0.02 \\
\hline \multicolumn{5}{|l|}{ Itacorubi .F } \\
\hline R. mangle $x$ A. schaueriana (Winter) & 1 & 41 & 0.11 & 0.73 \\
\hline R. mangle $\times$ A. schaueriana (Summer) & 1 & 44 & 39.4 & $<0.01$ \\
\hline
\end{tabular}


Another study that evaluated leaf breakdown of the same species observed changes in the decay rates of $A$. schaueriana when submersed and not submersed in mangroves of southeastern Brazil (Moura, 1997), which also indicates that environmental conditions are important. On the other hand, when comparing our decay rates for A. schaueriana with other studies in south and southeastern Brazil (Adaime, 1985; Panitz, 1986; Sessegolo and Lana, 1991), similar values were observed, except that registered in the south Brazil (Parana) by Barroso-Matos et al. (2012; Table 4). However, we found similar values during the winter, but they were lower than the summer values for $R$. mangle that were obtained by Aké-Castillo et al. (2006) in the Gulf of Mexico, Juman (2005) in the Tobago, and also other studies in south and southeastern Brazil (Adaime, 1985; Panitz, 1986; Sessegolo and Lana, 1991; Silva et al., 1998; Barroso-Matos et al., 2012). On the other hand, when comparing our decay rates for $R$. mangle to those of the warmer regions in northeastern Brazil, higher values have been recorded in other studies (Oliveira et al., 2013; Table 4). This suggested that latitude, along with environmental effects, primarily temperature, could be a key factor for leaf breakdown (Table 4).

Leaf breakdown was higher during the summer (in higher temperatures) than during the winter, suggesting that this variable exerts a strong influence on this process (Mfilinge and Tsuchiya, 2008) and corroborating the hypothesis of this study. Other studies have shown temperature to be an important factor for decomposition in mangroves, where only a few degrees can be sufficient to increase the metabolic activity of the decomposer community or even accelerate leaf degradation, consequently accelerating the process (Suberkropp and Chauvet, 1995; Kristensen et al., 2008). Another important aspect is the existence of optimal temperatures for decomposers that are required to develop their role in the ecosystem. Low temperatures measured in winter may impair the decomposer communities (Mfilinge and Tsuchiya, 2008). Such results help contribute to the existence of temporal variation in the functioning of the studied mangroves, altering leaf breakdown.

Table 4. Localization, decomposition rates $(k)$, condition of experiment and authors of studies on mangroves with detritus of $A$. schaueriana (A) and $R$. mangle (B).

\begin{tabular}{|c|c|c|c|}
\hline localization & $k$ & Condition of experiment & Author \\
\hline \multicolumn{4}{|l|}{ Rhizophora mangle .A } \\
\hline Florianópolis, SC (Brazil) & -0.007 & submerged - winter - Itacorubi & This study \\
\hline Florianópolis, SC (Brazil) & -0.005 & submerged - winter - Ratones & This study \\
\hline Florianópolis, SC (Brazil) & -0.013 & submerged - summer - Itacorubi & This study \\
\hline Florianópolis, SC (Brazil) & -0.015 & submerged - summer - Ratones & This study \\
\hline Gulf of Mexico & $-0.005 /-0.008$ & submerged & Aké-Castillo et al. (2006) \\
\hline Ilhéus, BA (Brazil) & -0.022 & submerged & Oliveira et al. (2013) \\
\hline Ilhéus, BA (Brazil) & $-0.016 /-0.020$ & not submerged & Oliveira et al. (2013) \\
\hline Rio de Janeiro (Brazil) & -0.003 & submerged & Barroso-Matos et al. (2012) \\
\hline Paraná (Brazil) & $-0.015 /-0.006$ & submerged & Sessegolo and Lana (1991) \\
\hline Leeward coast (south Tobago) & $-0.012 /-0.001$ & submerged & Juman (2005) \\
\hline Rio de Janeiro (Brazil) & -0.009 & submerged & Silva et al. (1998) \\
\hline Florianopolis (Brazil) & -0.006 & submerged & Panitz (1986) \\
\hline São Paulo (Brazil) & -0.008 & not submerged & Adaime (1985) \\
\hline \multicolumn{4}{|l|}{ Avicennia schaueriana.B } \\
\hline Florianópolis, SC (Brazil) & -0.006 & submerged - winter - Itacorubi & This study \\
\hline Florianópolis, SC (Brazil) & -0.005 & submerged - winter - Ratones & This study \\
\hline Florianópolis, SC (Brazil) & -0.010 & submerged - summer - Itacorubi & This study \\
\hline Florianópolis, SC (Brazil) & -0.009 & submerged - summer - Ratones & This study \\
\hline Santos, SP (Brazil) & -0.009 & not submerged - site 1 & Moura (1997) \\
\hline Santos, SP (Brazil) & -0.005 & not submerged - site 2 & Moura (1997) \\
\hline Santos, SP (Brazil) & -0.016 & submerged - site 1 & Moura (1997) \\
\hline Santos, SP (Brazil) & -0.012 & submerged - site 2 & Moura (1997) \\
\hline Rio de Janeiro (Brazil) & -0.005 & submerged & Barroso-Matos et al. (2012) \\
\hline Paraná (Brazil) & -0.043 & submerged & Sessegolo and Lana (1991) \\
\hline Florianopolis (Brazil) & -0.011 & submerged & Panitz (1986) \\
\hline São Paulo (Brazil) & -0.012 & not submerged & Adaime (1985) \\
\hline
\end{tabular}


No significant differences were detected for the mass loss of both species between sites in the winter, which is possibly due to a low variation of environmental factors, especially temperature, during this period. In some mangroves, a constant exchange of material and energy between marine and terrestrial ecosystems can be observed, and these exchanges can be intensified during the winter due to low temporal variation, especially with temperature because this variable can directly or indirectly modify other abiotic variables (Lugo and Snedaker, 1974; Fernandes, 2003), which explains our results.

For the mass loss between detritus types, a significant difference was found during the summer but not the winter. These temporal differences could be because $R$. mangle was more susceptible to these changes, which explains its higher leaf breakdown in the summer. Variation in the amount of foliage used by the decomposers is also present (Robertson, 1988). For example, in forests dominated by Ceriops sp., the foliage is brought underground and eaten by crabs, whereas in forests dominated by Rhizophora sp., the foliage is utilized through microbial action (Robertson, 1988), indicating a possible microbial preference for $R$. mangle. Nevertheless, these estequiometric relationships, coupled with the decomposer community, require further investigation in future studies.

We also observed temporal variation in mangrove functioning during the summer, detecting a negative association only at the highest temperatures with the remaining mass. As previously discussed in detail, the effects of temperature influence the quality of detritus and the metabolism of the decomposer community, which consequently affects the processing of organic material, thus accelerating the process (Robertson, 1988; Cuzzuol and Campos, 2001; Mfilinge and Tsuchiya, 2008). During the winter, the remaining mass was negatively associated with electrical conductivity and positively associated with dissolved oxygen. High values of electrical conductivity may be associated with a high nutrient concentration in the water (Maillard and Santos, 2008), which enables the microorganism decomposers to obtain the required nutrients to increase their metabolism and accelerate leaf breakdown (Rosemond et al., 2002; Gafner and Robinson, 2007). On the other hand, our data are limited in their explanation of the positive relationship between the remaining mass with dissolved oxygen. However, we can infer that high values of oxygen indirectly indicate increased photosynthetic production and a preferential use of this resource for the ecosystem food web (Vannote et al., 1980; Gessner et al., 1999). This would be easier for the decomposition of autochthones organic matter when compared to allochthonous (Vannote et al., 1980; Gessner et al., 1999), but this result requires further investigation. The former indicates that environmental conditions can positively or negatively influence this process.

In general, our data corroborate the hypothesis that higher decomposition rates occur with elevated water temperatures and greater electrical conductivity concentrations in mangroves. However, the positive relationship between the remaining mass and dissolved oxygen was contrary to our hypothesis. Therefore, these abiotic variables can affect the decomposition of the senescent leaves; consequently, it is an important process for mangrove ecosystem functioning.

\section{Acknowledgements}

Special thanks to the Laboratory of Freshwater Ecology, the ICMBio, the Program in Plant Biology and Program in Ecology of the Universidade Federal de Santa Catarina for the logistical support and infrastructure provided. We also thank CAPES for a PhD scholarship. Thank the two anonymous reviewers who contributed so much to improve this study.

\section{References}

ADAIME, RR. 1985. Produção do bosque de mangue da Gamboa Nóbrega (Cananéia, 25 Lat. S-Brasil). [Tese]. São Paulo: Universidade de São Paulo.

AKÉ-CASTILLO, JA., VÁZQUEZ, G. and LÓPEZPORTILLO, J. 2006. Litterfall and decomposition of Rhizophora mangle L. in a coastal lagoon in the southern Gulf of Mexico. Hydrobiologia, vol. 559, no. 1, p. 101-111. http://dx.doi.org/10.1007/ s10750-005-0959-x

ALLAN, JD. and CASTILLO, MM. 2007. Stream Ecology: Structure and function of running waters. 2nd ed. Springer. $436 \mathrm{p}$.

BARROSO-MATOS, T., BERNINI, E. and REZENDE, CE. 2012. Decomposition of mangrove leaves in the estuary of Paraíba do Sul River Rio de Janeiro, Brazil. Latin American Journal of Aquatic Research, vol. 40, no. 2, p. 398-407. http://dx.doi.org/10.3856/vol40issue2-fulltext-14

BIANCHINI JUNIOR, I. 1999. Aspectos do processo de decomposição nos ecossistemas aquáticos continentais. In POMPÊO, MLM. (Org.). Perspectivas da Limnologia no Brasil. São Luis: Gráfica e Editora Uniáo. p. 21-43. 
BOUILLON, S., CONNOLLY, RM. and LEE, SY. 2008. Organic matter exchange and cycling in mangrove ecosystems: Recent insights from stable isotope studies. Journal of Sea Research, vol. 59, no. 1-2, p. 4458. http://dx.doi.org/10.1016/j.seares.2007.05.001

CASTILHO-WESTPHAL, GG., OSTRENSKY, A., PIE, MR. and BOEGER, WA. 2008. Estado da arte das pesquisas com o caranguejo-uçá, Ucides cordatus. Archives of Veterinary Science, vol. 13, no. 2, p. 151-166.

CRAWLEY, MJ. 2007. The R Book. Wiley. p. 449.

CUZZUOL, GRF. and CAMPOS, A. 2001. Aspectos nutricionais na vegetação de manguezal do estuário do Rio Mucuri, Bahia, Brasil. Revista Brasileira de Botânica, vol. 24, no. 2, p. 25-40.

DE'ATH, G. 2002. Multivariate Regression Trees: A New Technique for Modeling Species-Environment Relationships. Ecology, vol. 83, no. 4, p. 1105-1117.

FERNANDES, MEB. 2003. Produção primária: serapilheira. In FERNANDES, MEB. (Ed.). Os manguezais da costa norte brasileira. São Luís: Fundação Rio Bacanga. p. 61-78.

GAFNER, K. and ROBINSON, CT. 2007. Nutrient enrichment influences the responses of stream macroinvertebrates to disturbance. Journal of North American Benthological Society, vol. 26, no. 1, p. 92-102. http://dx.doi.org/10.1899/08873593(2007)26[92:NEITRO]2.0.CO;2

GESSNER, MO., CHAUVET, E. and DOBSON, M. 1999. A perspective on leaf litter breakdown in streams. Oikos, vol. 85 , no. 2, p. 377-384. http:// dx.doi.org/10.2307/3546505

GONÇALVES, JFJ., MARTINS, RT., OTTONI, BMP. and COUCEIRO, SRM. 2013. Uma visão sobre a decomposição foliar em sistemas aquáticos brasileiros. In HAMADA, N., NESSIMIAN, JL. and QUERINO, RB. (Eds.). Insetos aquáticos: biologia, ecologia e taxonomia.

GONÇALVES JUNIOR, JF., GRAÇA, MAS. and CALLISTO, M. 2006a. Leaf-litter breakdown in 3 streams in temperate, Mediterranean, and tropical Cerrado climates. Journal of the North American Benthological Society, vol. 25, no. 2, p. 344-355. http:// dx.doi.org/10.1899/0887-3593(2006)25[344:LBIS IT]2.0.CO;2

GONÇALVES JUNIOR, JF., FRANCA, JS. and CALLISTO, M. 2006b. Dynamics of allochthonous organic matter in a tropical Brazilian headstream. Brazilian Archives of Biology and Technology, vol. 49, no. 6, p. 967-973. http://dx.doi.org/10.1590/S151689132006000700014

GONÇALVES JUNIOR, JF., REZENDE, RS., FRANÇA, J. and CALLISTO, M. 2012a. Invertebrate colonization during leaf processing of native, exotic and artificial detritus in a tropical stream. Marine and Freshwater Research, vol. 63, no. 5, p. 428-439. http://dx.doi.org/10.1071/MF11172

GONÇALVES JUNIOR, JF., REZENDE, RS., MARTINS, NM. and GREGÓRIO, RS. 2012 b. Leaf breakdown in an Atlantic Rain Forest stream. Austral Ecology, vol. 37, no. 7, p. 807-815. http:// dx.doi.org/10.1111/j.1442-9993.2011.02341.x

GRAÇA, MAS., BARLOCHER, F. and GESSNER, MO. 2005. Methods to Study Litter Decomposition. Springer. p. 37.

GRANEK, E. and RUTTENBERG, BI. 2008. Changes in biotic and abiotic processes following mangrove clearing. Estuarine, Coastal and ShelfScience, vol. 80, no. 4, p. 555-562. http://dx.doi.org/10.1016/j. ecss.2008.09.012

GULIS, V. and SUBERKROPP, K. 2003. Interactions between stream fungi and bacteria associated with decomposing leaf litter ad different levels of nutrient availability. Aquatic Microbial Ecology, vol. 30, no. 1, p. 149-157. http://dx.doi.org/10.3354/ame030149

JUMAN, AR. 2005. Biomass, litterfall and decomposition rates for the fringed Rhizophora mangle forest lining the Bon Accord Lagoon, Tobago. Revista de Biología Tropical, vol. 53, no. 1, p. 207-217.

KRISTENSEN, E., BOUILLON, S., DITTMAR, T. and MARCHAND, C. 2008. Organic carbon dynamics in mangrove ecosystems: A review. Aquatic Botany, vol. 89, no. 2, p. 201-219. http://dx.doi. org/10.1016/j.aquabot.2007.12.005

LUGO, AE. and SNEDAKER, SC. 1974. The ecology of mangroves. Annual Review of Ecology and Systematics, vol. 5, no. 1, p. 39-64. http://dx.doi.org/10.1146/ annurev.es.05.110174.000351

MAILLARD, P. and SANTOS, NAP. 2008. A spatialstatistical approach for modeling the effect of nonpoint source pollution on different water quality parameters in the Velhas river watershed-Brazil. Journal of Environmental Management, vol. 86, no. 1, p. 158-170. PMid:17316961. http://dx.doi. org/10.1016/j.jenvman.2006.12.009

MFILINGE, PL. and TSUCHIYA, M. 2008. Effect of temperature on leaf litter consumption by grapsid crabs in a subtropical mangrove (Okinawa, Japan). Journal of Sea Research, vol. 59, no. 1-2, p. 94-102. http://dx.doi.org/10.1016/j.seares.2007.07.004

MORETTI, MS., GONÇALVES, JFGJR. and CALLISTO, M. 2007a. Leaf breakdown in two tropical streams: Differences between single and mixed species packs. Limnologica, vol. 37, no. 3, p. 250-258. http://dx.doi.org/10.1016/j.limno.2007.01.003

MORETTI, MS., GONÇALVES JR, JF., LIGEIRO, R. and CALLISTO, M. 2007b. Invertebrates colonization on native trees leaves in a neotropical stream (Brazil). International Review of Hydrobiology, vol. 92, no. 2, p. 199-210. http://dx.doi.org/10.1002/ iroh.200510957 
MOURA, DO. 1997. Decomposição de folhas em manguezais na região de Bertioga, São Paulo, Brasil. [Dissertação]. São Paulo: Universidade de São Paulo.

OLIVEIRA, AB., RIZZO, AE. and COUTO, ECG. 2013. Assessing Decomposition Rates of Rhizophora mangle and Laguncularia racemosa Leaves in a Tropical. Estuaries and Coasts, vol. 36, no 6, p. 13541362. In press. http://dx.doi.org/10.1007/s12237013-9627-y

ONG, JE. 1995. The ecology of mangrove conservation and management. Hydrobiologia, vol. 295, no. 1, p. 343-351.

PANITZ, CMN. 1986. Produção e decomposição de serapilheira no mangue do rio Itacorubi, Ilha de Santa Catarina, Florianópolis, Brasil. [Tese]. São Carlos: Universidade Federal de São Carlos.

PETERSEN, RC. and CUMMINS, KW. 1974. Leaf processing in a woodland stream. Freshwater Biology, vol. 4, no. 4, p. 345-368.

QUINTINO, V., SANGIORGIO, F., RICARDO, F., MAMEDE, R., PIRES, A., FREITAS R., RODRIGUES, AM. and BASSET, A. 2009. In situ experimental study of reed leaf decomposition along a full salinity gradient. Estuarine, Coastal and Shelf Science, vol. 85, no. 3, p. 497-506. http://dx.doi. org/10.1016/j.ecss.2009.09.016

R Development Core Team. 2008. R: A language and environment for statistical computing. Vienna: $\mathrm{R}$ Foundation for Statistical Computing. Available from: <http://www.R-project.org>. Access in: Sept 2012.

REZENDE, RS., GONÇALVES JUNIOR, JF. and PETRUCIO, MM. 2010. Leaf breakdown and invertebrate colonization of Eucalyptus grandis (Myrtaceae) and Hirtella glandulosa (Chrysobalanaceae) in two Neotropical lakes. Acta Limnologica Brasiliensia, vol. 22, no. 2, p. 23-34.

RIETZ, DN. and HAYNES, RJ. 2003. Effects of irrigation induced salinity and sodicity on soil microbial activity. Soil Biology and Biochemistry, vol. 35 , no. 1, p. 845-854.

ROACHE, MC., BAILEY, PC. and BOON, PI. 2006. Effects of salinity on the decay of the freshwater macrophyte, Triglochin procerum. Journal of Aquatic Botany, vol. 84, no. 1, p. 45-52. http://dx.doi. org/10.1016/j.aquabot.2005.07.014

ROBERTSON, AI. 1988. Decomposition of mangrove leaf litter in tropical Australia. Journal of Experimental Marine Biology and Ecology, vol. 116, no. 3, p. 235-247. http://dx.doi.org/10.1016/00220981(88)90029-9

ROSEMOND, AD., PRINGLE, CM., RAMIREZ, A., PAUL, MJ. and MEYER, JL. 2002. Landscape variation in phosphorus concentration and effects on detritus-based tropical streams. Limnology and Oceanography, vol. 47, no. 1, p. 278-289. http:// dx.doi.org/10.4319/lo.2002.47.1.0278

SÁNCHEZ-ANDRÉS, R., SÁNCHEZ-CARRILLO, S., ALATORRE, LC., CIRUJANO, S. and ÁLVAREZCOBELAS, M. 2010. Litterfall dynamics and nutrient decomposition of arid mangroves in the Gulf of California: Their role sustaining ecosystem heterotrophy. Estuarine, Coastal and Shelf Science, vol. 89, no. 3, p. 191-199. http://dx.doi. org/10.1016/j.ecss.2010.07.005

SESSEGOLO, GC. and LANA, PC. 1991. Decomposition of Rhizophora mangle, Laguncularia racemosa e Avicennia schaueriana leaves in a Mangrove of Paranaguá Bay (Southeastern Brazil). Botanic Marine, vol. 34, no. 2, p. 285-289.

SHAFER, DJ. and ROBERTS, TH. 2007. Long-term development of tidal mitigation wetlands in Florida. Wetlands Ecology and Management, vol. 16, no. 1, p. 23-31. http://dx.doi.org/10.1007/s11273-0079044-8

SILVA, CAR., LACERDA, LD., OVALLE, AR. and REZENDE, CE. 1998. The dynamics of heavy metals through litterfall and decomposition in a red mangrove forest. Mangroves Salt Marshes, vol. 2, no. 1, p. 149-157.

SILVA, MAB., BERNINI, E. and CARMO, TMS. 2005. Características estruturais de bosques de mangue do estuário do rio São Mateus, ES, Brasil. Acta Botanica Brasilica, vol. 19, no. 3, p. 465-471. http://dx.doi. org/10.1590/S0102-33062005000300006

SUBERKROPP, K. and CHAUVET, E. 1995. Regulation of leaf breakdown by fungi in streams: influences of water chemistry. Ecology, vol. 76, no. 5, p. 14331445. http://dx.doi.org/10.2307/1938146

VANNOTE, RL., MINSHALL, GW., CUMMINS, KW., SEDELL, JR. and CUSHING, CE. 1980. The river continuum concept. Canadian Journal of Fisheries and Aquatic Sciences, vol. 37, no. 1, p. 130137. http://dx.doi.org/10.1139/f80-017

WANTZEN, KM. and WAGNER, R. 2006. Detritus processing by invertebrate shredders: a neotropicaltemperate comparison. Journal of the North American Benthological Society, vol. 25, no. 1, p. 216-232. http:// dx.doi.org/10.1899/0887-3593(2006)25[216:DPBI SA]2.0.CO;2 